\title{
EVOLUTION OF THE URBAN SYSTEM OF BOTOŞANI COUNTY
}

\author{
Gabriel PASCARIU \\ "Ion Mincu" University of Architecture and Urbanism, Bucharest, Romania
}

\begin{abstract}
The Botoşani County is part of one of the most marginal and least developed NUTS II regions of the EU. The county itself is one of the least developed within the region. However, it has an interesting history and evolution and a geographical position which can become an opportunity for economic, social, cultural and urban development. The urban structure is now, rather fragile and vulnerable to present social and economic trends and crises. During the last 80-90 years, under the impact of political changes and influences, the urban system was subjected to artificial and not always sound and durable developments. The pre-eminence of political, administrative and economic factors led to competition among the main urban centres which had as result winners and losers. The lack of specific urban development policies created in the end a mono-centric and unbalanced urban system. Recent decisions create premises for future evolutions towards a more coherent and cohesive system if sound strategies and policies are implemented by local authorities.
\end{abstract}

Key Words: human settlements, urban system, territory, Botoşani County, North-East Region, Romania

\section{Geographical position and general data}

Botoşani County is located in the extreme North-eastern corner of Romania, at the border with Ukraine to the North and Republic of Moldova to the East (Fig. 1). In terms of surface and population, the county is one of medium-low size. With $4,986 \mathrm{sqkm}$ it ranks the $29^{\text {th }}$ among the 41 counties of Romania ${ }^{1)}$. In terms of demographic size, it ranks on the $22^{\text {nd }}$ position, with 448,749 inhabitants in $2010^{2}$. It is crossed by the $27^{\text {th }}$ degree meridian and by the $48^{\text {th }}$ degree parallel.

The county is part of one of the eight development regions of the country: North-east Region, which is among the least developed regions of the European Union. It is also the smallest, in both terms of surface and population among the 6 counties of the region. During the last period of time, the North-east Development Region in Romania has shared the last places among the European Regions according to the GDP /inhabitant expressed in PPS ${ }^{3)}$ together with the Severozapaden Region in Bulgaria. In 2007, the North-east Region slightly overcame the threshold of $25 \%$ of the average GDP of EU27. Though, Botoşani County is part of an area which is not only a geographical extreme at the Eastern border of the EU, but also a negative pole of economic and social development of the EU. It is worth to notice actually that the 4 extreme Eastern regions of the EU (North-east and South-east Muntenia in Romania and

1) Romania is divided into counties, towns and communes. It has 41 counties, 320 cities and towns and 2860 communes (according to the Statistical Yearbook of Romania, 2009). The 41 counties and the capital city of Bucharest are NUTS III administrative units. There are also divisions of 8 development regions (NUTS II level) and 4 macro-statistical regions (NUTS I level), which are not administrative units.

2) Population of Romania at 1st of January 2010, INS (the National Institute for Statistics).

3) Purchasing power standards, according to Eurostat data. Eurostat Newsrelease, February 2009 and February 2010. 


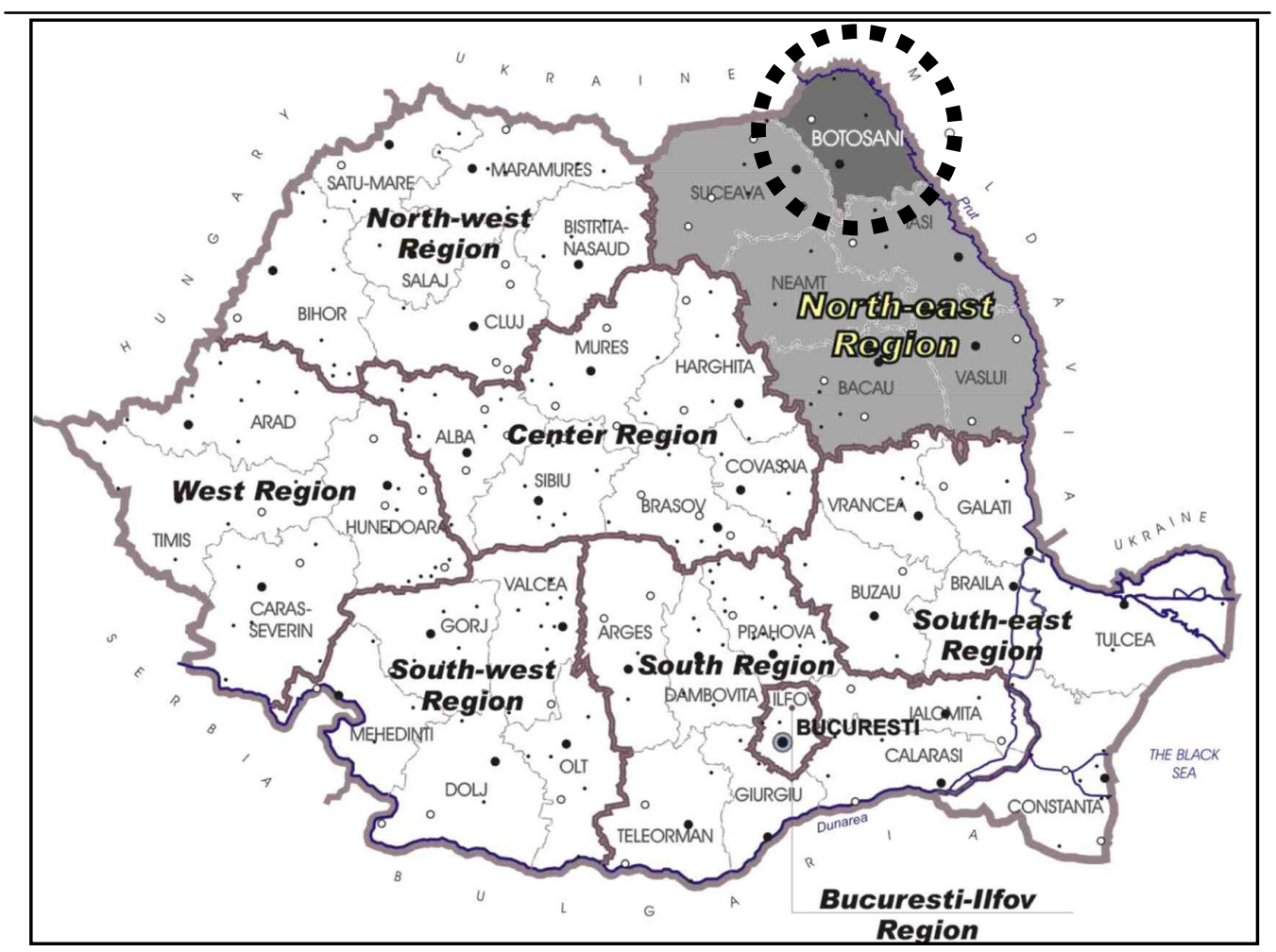

Fig. 1- Position of Botoşani County in Romania and in the North-East Region

Severoiztochen and Yugoiztochen in Bulgaria) are among the 10 least developed regions of the European Community (Fig. 2) according to the most recent data of Eurostat.

Since 1998, when the 8 development regions have been set up in Romania, the North-east has held the last position in terms of level of economic and social development. In fact, the gap between North-east and the other regions has increased during the following decade as described in Table 1 and represented in Figure nr. 3. In terms of difference, as percentage of Romanian GDP /inhabitant, the gap between North-east and Bucureşti-Ilfov Region has almost doubled in 2007 as against 1998 and in terms of proportions it increased from 2.0 in 1998 up to 3.5 in 2007. Botoşani County is also since 1998 one of the least developed counties of Romania and of the region too. In 1996, the first study on regional disparities in Romania ranked Botoşani County as second last by the General Index of Development ${ }^{4)}$ computed for 1994 year. Its position within the region has not improved since, being the $5^{\text {th }}$ among the 6 counties of the region (the $6^{\text {th }}$ is Vaslui County, which was ranked on the last position in 1994 too). In 2007, it ranked on the $38^{\text {th }}$ position among the 41 counties (Bucharest not included).

The GDP /inhabitant of Botoşani County, in 2007 represented $85.5 \%$ of the regional GDP /

4) The Global Development Index has been computed on the basis of a number of 17 indicators, using a standardizing statistical method and computing a Hull score. It has been published in the report on "Regional Disparities in Romania" (Rambøll, 1996). 
inhabitant and only $54 \%$ of the national GDP /inhabitant ${ }^{5)}$. The present condition of the county is due mainly to its peripheral position, combined with weak accessibility, poor infrastructure and an economy mostly based on primary sector. It also has a rather low level of urbanisation, being ranked among the ten most rural counties in Romania.

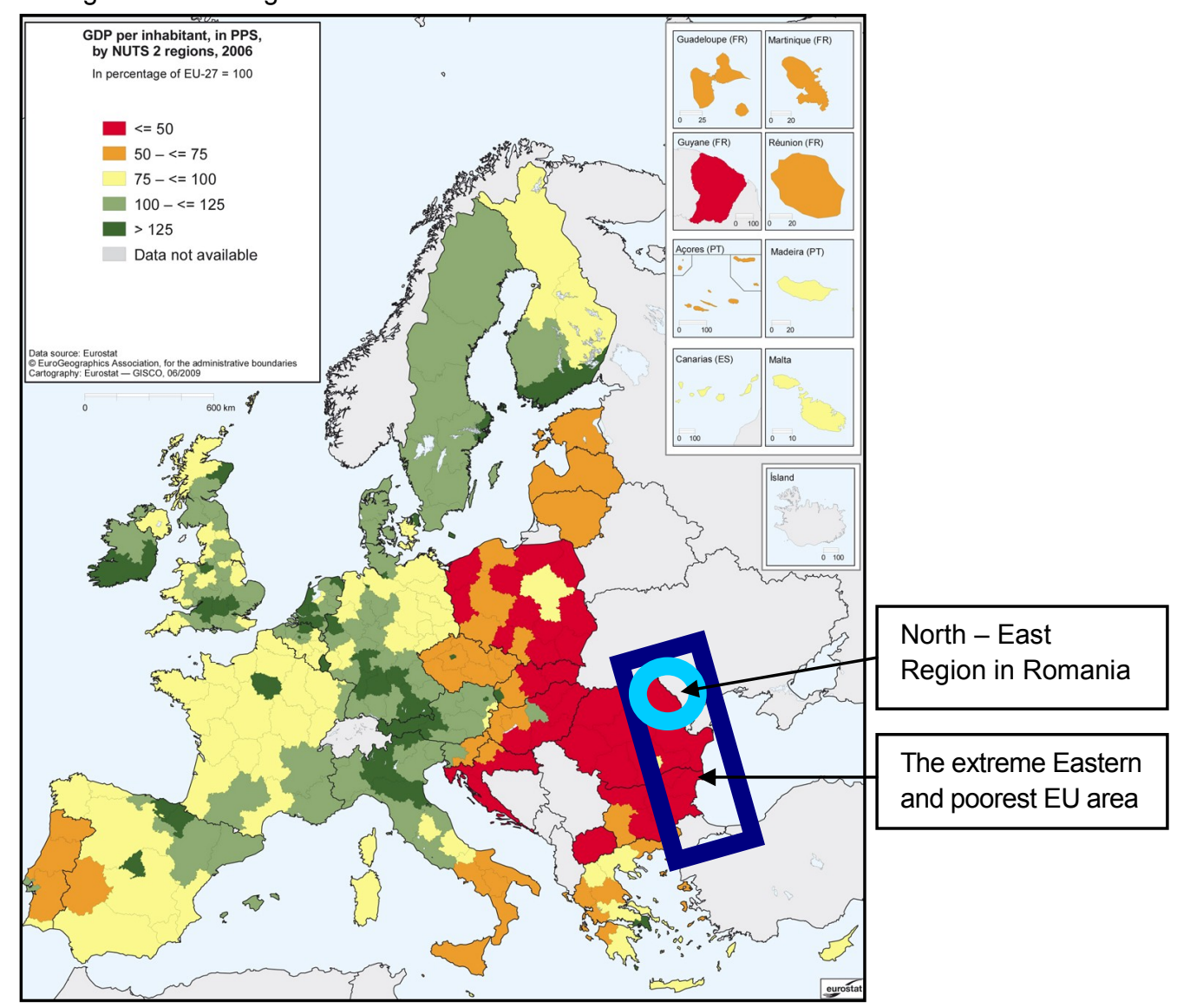

Fig. 2 - Position of the North-East region in EU (on a map from Eurostat regional yearbook 2009)

The geography of the county is characterised by low altitudes, $80 \%$ of the county being part of the Moldavian Plain, having 100 to 300 meters height, whiles the rest of $20 \%$ is being covered by low hills of 400 to 600 meters height, in the West side along the Siret river. A transversal section of the county shows a general slope form West to East, form the Siret Hills area to the low valley of the Prut river, which actually forms a long border of around $195 \mathrm{~km}$ to North and East. There is also a smoother slope of the land going form North-west to South-east, which determines the general flow of the main waters of the county, most of them being part of the Prut river basin (Fig. 4). There is a very strong connection between the geography and the and 2009.

5) Data computed on the basis of statistical data from the Romanian Statistical Yearbook, 2008 
main waters network of the county and the spatial structure of the human settlements (Fig. 5). Most of the settlements of the county are concentrated within the high plain areas of West and North whereas the rest developed along the valleys of the main rivers: Jijia, Başeu, Sitna and Prut.

\section{Evolution of GDP /inhabitant as \% of Romania $100 \%$ GDP}

\begin{tabular}{|l|r|r|r|}
\hline \multirow{2}{*}{ Development regions } & \multicolumn{3}{|c|}{ Year of reference } \\
\cline { 2 - 4 } & \multicolumn{1}{|c|}{1998} & \multicolumn{1}{c|}{2004} & \multicolumn{1}{c|}{$\mathbf{2 0 0 7}$} \\
\hline Bucureşti-Ilfov & $\mathbf{1 6 2 . 2}$ & $\mathbf{1 9 1 . 5}$ & $\mathbf{2 2 2 . 8}$ \\
\hline West & 100.9 & 114.7 & $\mathbf{1 1 5 . 7}$ \\
\hline Centre & 105.9 & 104.2 & $\mathbf{1 0 1 . 4}$ \\
\hline North-West & 95.5 & 97.2 & $\mathbf{9 6 . 4}$ \\
\hline South & 85.8 & 83.4 & $\mathbf{8 1 . 6}$ \\
\hline South-East & 100.1 & 90.7 & $\mathbf{8 1 . 0}$ \\
\hline South-West & 90.0 & 83.3 & $\mathbf{7 8 . 2}$ \\
\hline North-East & $\mathbf{7 9 . 8}$ & $\mathbf{6 9 . 2}$ & $\mathbf{6 3 . 9}$ \\
\hline Difference of extremes in \% & 82.4 & 122.3 & $\mathbf{1 5 8 . 9}$ \\
\hline Report between the extremes & 2.0 & 2.8 & $\mathbf{3 . 5}$ \\
\hline
\end{tabular}

Source: data for 1998 and 2004 are from the Regional Operational Programme 20072013; data for 2007 are computed according to data from the Romanian Statistical Yearbook 2009.

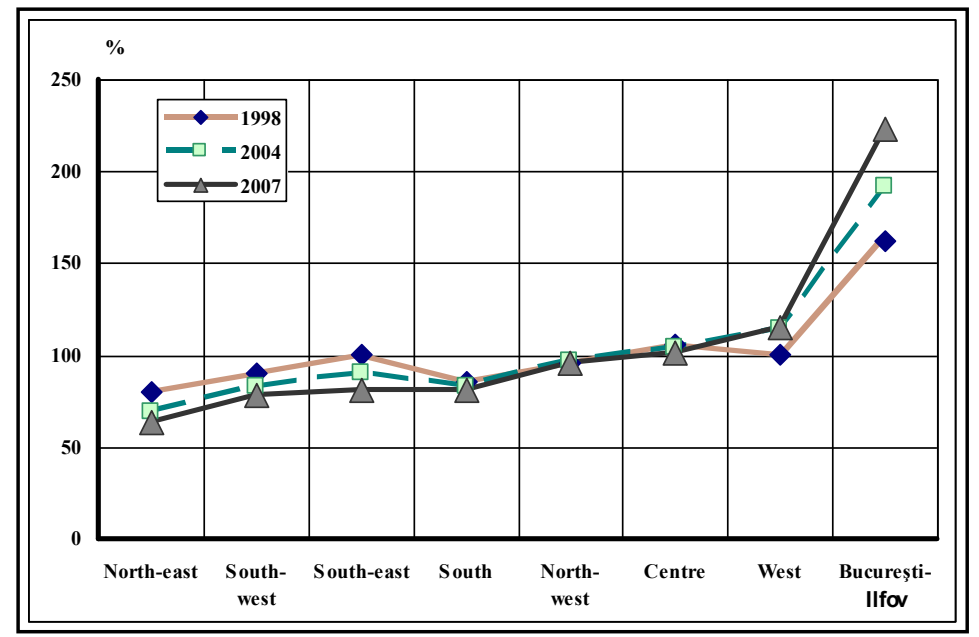

Fig. 3 - Evolution of regional GDP /inhabitant between 1998 and 2007(data for 1998 and 2004 are from the Regional Operational Programme 2007-2013; data for 2007 are computed according to data from the Romanian Statistical Yearbook 2009). 


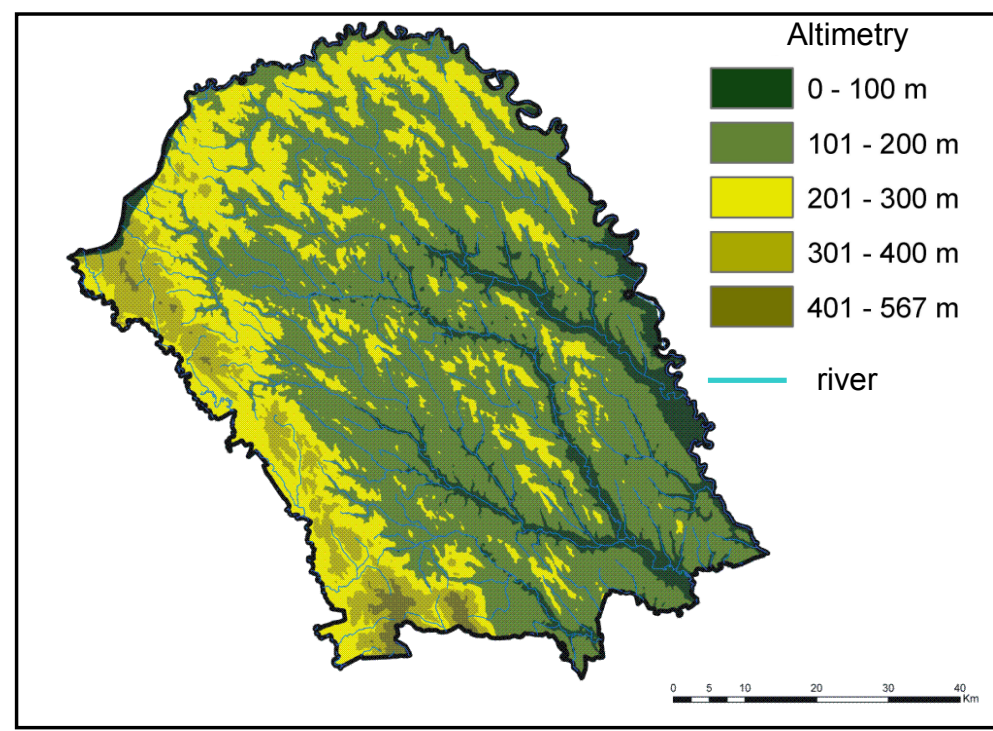

Fig. 4 - Geographic map of Botoşani County showing the general North-west to Southeast slope. The highest point is located in the South-western corner - Tudora Hills (map designed by CICADIT, 2009).

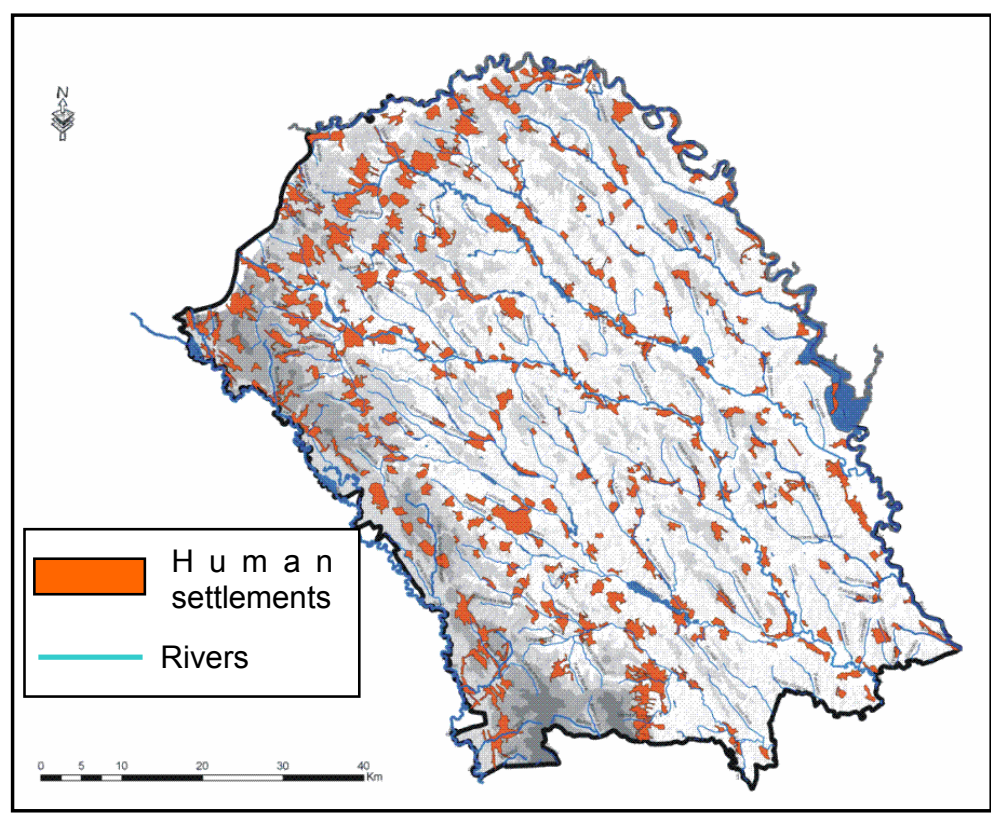

Fig. 5 - Geographic map of Botoşani County showing the general North-west to Southeast direction of the water flows (map designed by CICADIT, 2009). 


\section{Historic evolution of the administrative territory}

The present territory of Botoşani County as it is now, is only 40 years old. During several centuries of documentary records, there have been various stages of administrative and territorial changes. In spite of its geographical continuity and homogeneity, the present territory has been artificially divided into two counties: North and South. However, within few interruptions "the county" as the most important sub-state level of administrative organisation survived along the centuries.

The first historic records of administrative organisation are from the $14^{\text {th }}$ and $15^{\text {th }}$ century and refer to two main counties: Hârlău, corresponding to the southern part of the county and Dorohoi, covering the northern part of the present territory. The two entities have lasted with various minor changes until the end of the $4^{\text {th }}$ decade of the $20^{\text {th }}$ century as part of Moldavian State until 1859 , then of the so called Unified States of Moldavia and Walachia until 1881 and than as part of the Romanian Kingdom until $1947^{6}$. Their western, northern and eastern limits were defined by natural boundaries: the rivers Prut (East and North) and Siret (to the West). These natural limits were a stable element for defining the shape and size of the two administrative units (minor variations were registered on the North-western corner). The southern boundary was more flexible and varied a little bit during the history. In the $17^{\text {th }}$ century, Hârlău County was divided and Botoşani County was set up. The town of Botoşani became the capital city, replacing the previous one Hârlău, a commercial town that started to decay. The new capital preserved its status until 1938, whereas Dorohoi has been replaced by other towns for a short period of time in the first half of the $19^{\text {th }}$ century. For all that time the two capitals have been the main urban centres of the two counties. During the $19^{\text {th }}$ century some other settlements got the status of town or "târg" (small commercial town) and territorial roles as "plasa" centres $^{7)}$ : Mihăileni (which was also capital of Dorohoi County from 1835 to 1950), Darabani and Săveni in the second half of the 19th century, but most of all Ştefăneşti, also known as Ştefăneştii and Ştefăneşti Târg, which is mentioned as an important settlement since the $16^{\text {th }}$ century. It is said that by the beginning of the $17^{\text {th }}$ century, the settlement "had 2,000 dwellings, an equivalent of 10,000 inhabitants" (Giurescu, 1967). It is named a town by various historians of the $17^{\text {th }}$ and $18^{\text {th }}$ centuries $^{8)}$. Yet, its evolution was regressive and by the beginning of the $19^{\text {th }}$ century it was not mentioned any more as an important settlement. It recovers for a short period of time during the first half of the $20^{\text {th }}$ century. Some basic features of these towns were the commercial character and the important weight of Jewish population. During most of the time the urban structure of Dorohoi County has been more developed and balanced than the one of Botoşani County.

First significant administrative changes have occurred during the $3^{\text {rd }}$ decade of the $20^{\text {th }}$ century, due to frequent political changes and attempts for an optimum administrative pattern for the Romanian Kingdom, which grew much larger after the 1918 unification. Due to the increase of the territory of the country after the unification, the two counties were no more extreme border counties and the different attempts of administrative reorganisation have created new links and subordinations as they were integrated into various higher administrative levels. In 1929, an administrative reform ${ }^{9)}$ set up a regional level named "ministerial directorates" and placed them

6) Most of the information is based on the preliminary studies for the Botoşani County Territorial Physical Plan, Historic evolution of Botoşani County, Quattro Design, 2009.

7) "Plasa" is a traditional form of intercomunal organisation, with or without administrative status, along history. A larger commune or a town was a kind of a "central place".

8) C. Giurescu (1967), quotes Miron Costin, who names it a town (miasto in Polish) in 1684 in his "Poema Polonă" (The Polish Poem) and Dimitrie Cantemir, who calls it "oppidum" in Descirptio Moldavie (1714).

9) Law for local administrative organisation, from the 3rd of August 1929. 
in two different regions: Dorohoi was better connected to the northern territories of Bucovina region and to the city of Chernivsti, whereas Botoşani stayed connected to the southern part and to the city of laşi. Although this administrative structure did last two years only, it was soon followed by another Administrative Law, in 1938, with a higher impact. The 1938 Law $^{10)}$ reduced the importance of the counties and set up larger regional units called "ținuturi" (Fig. $6 b)$. The two counties have been once more integrated in two different "tinuturi": Dorohoi in Suceava (the capital was Chernivtsi) and Botoşani in Prut (the capital was laşi). In 1940 there has been again a come back to the previous territorial structure with counties being the most important administrative sub-national level. But after the fall of the monarchy in 1947, a new administrative model, of Soviet influence, was put into place. Once more large regions were set up as major territorial units, and counties were abolished and replaced by smaller units called

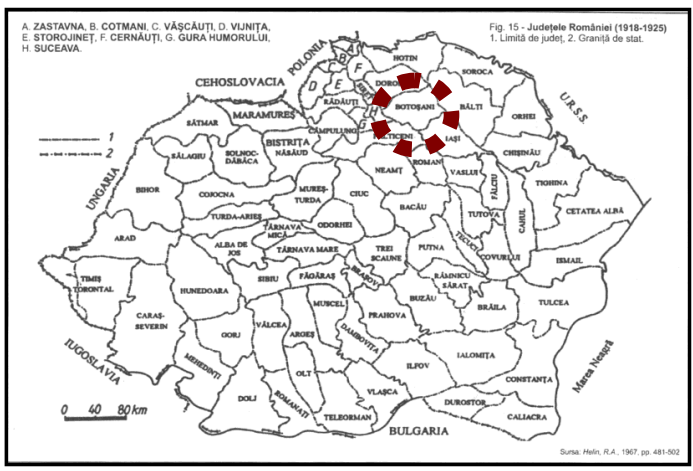

a)

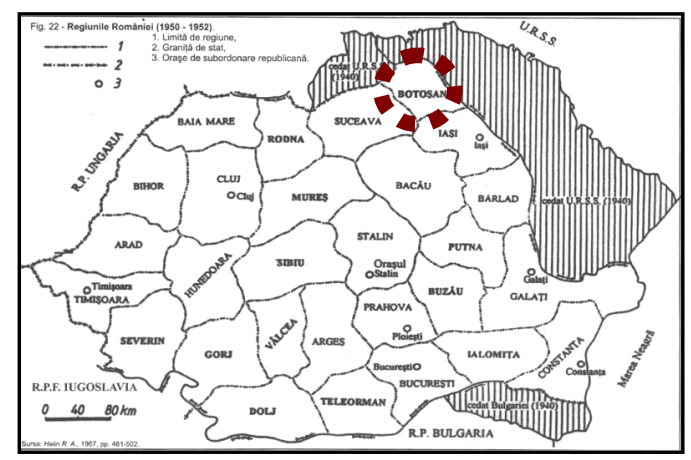

c)

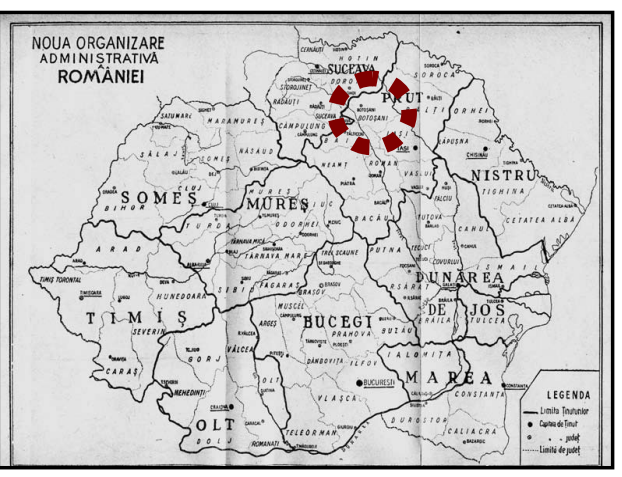

b)

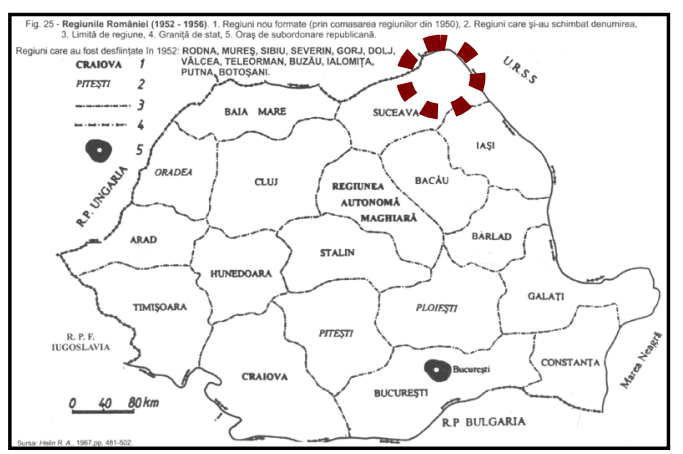

d)

Fig. 6 - Maps of different stages of evolution of the administrative territory of Botoşani County (a - Botoşani and Dorohoi counties as separate administrative units in the '20s; b - the two counties as parts of Suceava and Prut "ținuturi"; c - the two counties as part of the Botoşani region in 1950; $d$ - the two counties were dissolved within the region of Suceava from 1952 to 1968).

10) Administrative Law from the 14th of August 1938, was adopted on the bases of a new Constitution of the so called Royal Dictatorship of Carol the $2^{\text {nd }}$, in February 1938, replacing the Parliamentary monarchic system. 
"raioane", grouping around 20 urban and rural communes. By setting up a reduced number of territorial units, but twice or three times larger than the counties, the number of administrative urban centres have considerably reduced and allowed a concentration of public funds to a

smaller number of big cities, which were regional capitals. This policy favoured a fast growth of a limited number of cities whereas former county capitals which lost this status decayed (Săgeată, 2006, p.50). Dorohoi has suffered the most, whereas Botoşani took an important advantage as it became a regional capital for two years (1950-1952) (Fig. 6c). Yet, after 1952, the region of Botoşani became part of the larger region of Suceava until 1968 (Fig. 6d) ${ }^{11}$.

Although Botoşani city kept a regional role, its importance decreased in comparison to the city of Suceava (see fig. 8; in 1966, Suceava came in front of Botoşani, as a result of its regional capital status). In 1968, the administrative reform restored the traditional administrative structure based on counties, towns and communes as basic administrative units. Yet, the territorial delineations were not following the exact historical pattern, some new counties being set up, whereas some of the old ones were not reinstalled. The former Dorohoi and Botoşani counties (Fig. 6a) became one single unit having Botoşani as the capital city, as it is now. The instability of the administrative structure, recorded between 1930 and 1968, hampered and delayed the development of a solid and coherent urban system. On the other hand the last 4 decades of administrative stability allowed the consolidation of a rather fragile urban system with one winner - the capital city - and many losers (all the other former and present towns).

\section{Evolution of the urban system by the end of World War II}

The evolution of the urban system by the mid of the 5 decade of the $20^{\text {th }}$ century can be followed through the population data of the 1912 and 1930 censuses. There are no official figures for intermediate years, due to political events of the time: First World War from 1914 to 1919 and the process of unification of the Romanian provinces in 1918 followed by a period of time of difficult reorganisations and finally the major European conflict that led to World War II and to

The demographic evolution of urban centres during the first half of the $20^{\text {th }}$ century

\begin{tabular}{|r|l|r|r|r|r|r|}
\hline \multirow{2}{*}{} & \multirow{2}{*}{ Urban centres } & \multicolumn{4}{|c|}{ Number of inhabitants } & \multicolumn{1}{c|}{$\begin{array}{c}\text { Annual } \\
\text { growth }\end{array}$} \\
\cline { 3 - 7 } & & \multicolumn{1}{|c|}{1912} & \multicolumn{1}{c|}{1930} & \multicolumn{1}{c|}{1941} & \multicolumn{1}{c|}{1948} & \multicolumn{1}{c|}{$(\%)$} \\
\hline $\mathbf{1}$ & Botoşani & $\mathbf{3 3 3 7 1}$ & $\mathbf{3 2 3 5 5}$ & $\mathbf{3 0 4 6 4}$ & $\mathbf{2 9 9 8 5}$ & -0.30 \\
\hline $\mathbf{2}$ & Dorohoi & $\mathbf{1 4 7 5 5}$ & $\mathbf{1 5 8 6 6}$ & $\mathbf{1 5 9 0 1}$ & $\mathbf{1 5 4 1 2}$ & 0.12 \\
\hline 3 & Darabani & 8096 & $\mathbf{1 0 7 4 8}$ & $\mathbf{1 2 9 5 1}$ & $\mathbf{1 1 3 7 9}$ & 0.95 \\
\hline 4 & Ştefăneşti & 7310 & $\mathbf{8 8 9 1}$ & $\mathbf{9 7 6 4}$ & $\mathbf{7 7 7 0}$ & 0.17 \\
\hline 5 & Săveni & 5041 & $\mathbf{6 4 5 5}$ & $\mathbf{7 5 7 1}$ & $\mathbf{6 4 7 0}$ & 0.70 \\
\hline $\mathbf{6}$ & Mihăileni & $\mathbf{6 6 1 1}$ & $\mathbf{6 0 4 4}$ & $\mathbf{7 1 4 1}$ & $\mathbf{6 0 0 4}$ & -0.27 \\
\hline & & 301415 & 34660 & 404351 & 379120 & 0.64 \\
\hline Total population & $\mathbf{5}$ & $\mathbf{4 8 0 7 8}$ & $\mathbf{8 0 3 5 9}$ & $\mathbf{8 3 7 9 2}$ & $\mathbf{7 7 0 2 0}$ & 1.32 \\
\hline Urban population & $\mathbf{4 8 0 2}$ &
\end{tabular}

Source: Censuses statistical data, INS and personal compilations. The figures in bold are corresponding to the status of town during a certain period

11) Maps are reproduced as follows: $6 a, 6 c, 6 d$ from Sageata, 2006 and $6 b$ from the magazine "Urbanismul - serie nouă" (Urbanism - new series), no. 4, p. 9. 
major territorial losses for Romania. There is a long gap of almost 2 decades of unavailable statistical data from 1930 to 1948 except the 1941 record of population in 1941, for which data are disturbed due to the major movements of population caused by the war, including refugees that usually left bigger towns for smaller ones and rural areas. The main figures for the urban system of this interval are shown in the table 2.

The figures of this period of time are obviously, strongly marked by the major political events that occurred. The evolution of the urban centres was mostly circular: growing during the first part of the interval and decreasing in the second part (Fig. 7). Botoşani was the only one that constantly decreased, although in 1930 it got the status of city (municipiu).

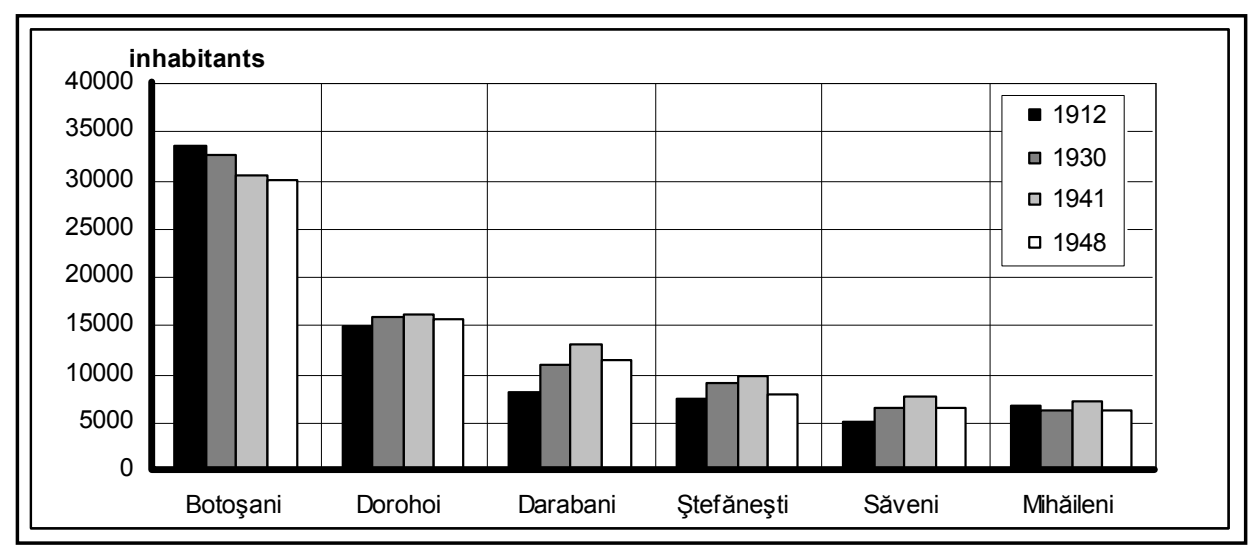

\section{Fig. 7 - The demographic evolution of urban centres during the first half of the $20^{\text {th }}$ century}

During the first half of the $20^{\text {th }}$ century, the present territory of Botoşani County was divided into two smaller counties, so one cannot discuss one urban system but two. Although smaller, the northern part, Dorohoi County had a more developed and balanced structure, due to the 4 towns, Dorohoi, Darabani, Mihăileni and Săveni, and a good territorial distribution. The urban system of the southern part, Botoşani County of that time, was much weaker with only two urban centres covering a larger territory. Although statistically, the urban population almost doubled (due to the increase of the number of towns), in fact the demographic size of the 6 urban centres increased by less than $2.5 \%$.

The predominant commercial character of the towns at that time was not able to provide significant growth and urban development during a troubled age. Practically, for almost half a century the urban system of the present Botoşani County was stationary, without any significant change of the urban hierarchy. The percentage urban population, of around $20 \%$ as against the whole territory, remained constant too. However, during this interval a number of rural communes played an important territorial role as "plasa" centres, such as Bucecea, Sulița, Vârfu Câmpului.

\section{Evolution of the urban system during the communist regime}

During the communist regime, since 1948 to 1989, the urban system of the two counties has been largely affected and transformed due to the public national authoritarian policies. During 
this 4 decades interval one can identify 3 different periods, in relation to changes of the administrative structure:

- a very short one from 1948 to 1950 , of continuity and after-war reconstruction; the administrative system and the urban centres remained unchanged;

- a longer one from 1950 to 1968 , defined by the administrative regional model of soviet influence and by the policy of massive investments in the industrial sector; an administrative reform frequently modified, followed by a restructuring of the human settlement system disturbed the evolution of the urban centres of former Botoşani and Dorohoi counties;

- the $3^{\text {rd }}$ and longest period, which begins with the administrative reform of 1968 and lasts till the fall of the regime in December 1989, is characterized by a certain development during the first decade and by stagnation during the second one; it is a much more stable period which favours the urban development in general but not in a very balanced way.

In 1948, the present territory of Botoşani County was still divided into two and counted 6 towns in total. The percentage of urban population (as referring to the present area) was slightly above $20 \%$. In 1950, the former towns of Darabani, Mihăileni, Săveni and Ştefăneşti Târg were degraded to the status of communes (rural administrative unit), as a follow up of the radical administrative reform. Botoşani city has been also degraded form the status of city (municipiu) he got in 1930, to that of a simple town. As a consequence the level of urban population has decreased to the minimum levels of the past 100 years of history of the territory ${ }^{12)}$.

A significant moment was the administrative reform of 1968, when for the first time the two neighbour counties were united under the name of Botoşani County. The town of Botoşani became the county capital and a city (municipiu) again, whereas the rural communes of Darabani and Săveni regained their urban status. Three other communes around Botoşani city became suburban communes. The urban system included 1 city (municipiu), 3 towns and 3 communes ${ }^{13)}$ with a total of 30 localities, as in the table below:

The urban system of Botoşani County as defined in 1968

Table 3

\begin{tabular}{|c|c|c|c|c|c|}
\hline \multirow[t]{2}{*}{$\begin{array}{c}\text { Cities } \\
\text { (municipii) }\end{array}$} & \multicolumn{2}{|c|}{$\begin{array}{l}\text { Suburban communes belong- } \\
\text { ing to the city }\end{array}$} & \multirow[t]{2}{*}{ Towns } & \multirow{2}{*}{$\begin{array}{l}\text { Villages } \\
\text { belonging to } \\
\text { towns }\end{array}$} & \multirow{2}{*}{$\begin{array}{l}\text { Other } \\
\text { settlements } \\
\text { belonging to } \\
\text { towns }\end{array}$} \\
\hline & $\begin{array}{l}\text { Capital } \\
\text { villages }\end{array}$ & Villages & & & \\
\hline \multirow[t]{3}{*}{ Botoşani } & Curteşti & $\begin{array}{l}\text { Agafton, Băiceni, } \\
\text { Hudum, Mănăsti- } \\
\text { rea Doamnei, } \\
\text { Orăşeni-Deal, } \\
\text { Orăşeni-Vale }\end{array}$ & Dorohoi & & $\begin{array}{l}\text { Dealu Mare, } \\
\text { Loturi Enescu, } \\
\text { Progresul }\end{array}$ \\
\hline & Răchiți & $\begin{array}{l}\text { Cişmea, Costeşti, } \\
\text { Roşiori }\end{array}$ & $\begin{array}{l}\text { Dara- } \\
\text { bani }\end{array}$ & $\begin{array}{l}\text { Bajura, } \\
\text { Eşanca, } \\
\text { Lişmănita }\end{array}$ & \\
\hline & Stăuceni & $\begin{array}{l}\text { Siliştea, Tocileni, } \\
\text { Victoria }\end{array}$ & Săveni & $\begin{array}{l}\text { Bodeasa, } \\
\text { Bozieni, } \\
\text { Chişcăreni, } \\
\text { Petricani, Sat } \\
\text { Nou }\end{array}$ & \\
\hline 1 & 3 & 12 & 3 & 8 & 3 \\
\hline
\end{tabular}

Source: Law 2 /1968 on administrative reform in Romania

12) At the 1956 and 1966 censuses, the urban population of Botoşani County (as against its present boundaries) was $10.5 \%$ and $11.7 \%$. 
Since 1968, the number of towns and cities remained steady (4) and the percentage of urban population continuously increased, up to $37 \%$ by the end of the period, in spite of the fact that in 1977 the category of suburban communes was annulled and the population of all communes was counted as being rural population. The urban population doubled during the 4 decades, from 77,000 in 1948 to 174,678 inhabitants in December $1989^{14}$, although the number of urban centres decreased from 6 to 4 . Botoşani city increased 4 times, from 29,145 in 1948 to 121,351 inhabitants by the end of the period, whereas Dorohoi has only doubled its population form about 15,000 to more than 32,000 along the same interval ${ }^{15}$. During these 40 years, the capital city of the county became a large city, increasing the "primacy report" from 1.9 to 3.7 and hosting in the end more than $25 \%$ of the whole population of the county in 1989 as against less than $8 \%$ in 1948. This spectacular increase was the consequence of the urban development policy of the communist regime, which encouraged the development of the capital cities of the counties, especially of the new ones, by concentration of investments especially in industrial sites and collective housing. Botoşani city was much more favoured in terms of resource distribution than Dorohoi, which was considered to represent the past whereas Botoşani was a symbol of the new age. The industrial sector has been much diversified form light to heavy industry and the city was also endowed with lot of social infrastructure for health, education, culture and sport /leisure. It became an important growth centre of the North-eastern part of the country, but unfortunately the large process of reconstruction affected an important part of the cultural heritage of the former commercial town.

Table 4

The demographic evolution of urban centres during the communist regime

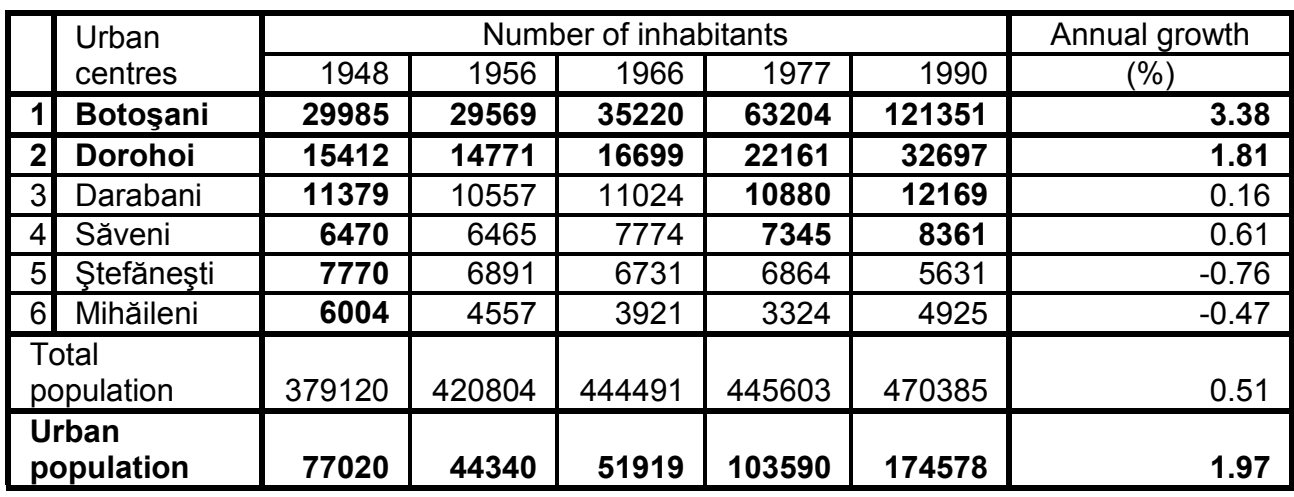

Source: Censuses statistical data, INS and personal compilations. The figures in bold are corresponding to the status of town during a certain period

The table above shows the rapid growth of the capital city as compared to all the other towns and to the general growth of the county population. It was obviously the main vector for urban growth during the communist period, but its growth was achieved on account of stagnation or decrease of other urban centres as well as of the rural settlements. Botoşani behaved as a

13) Between 1968 and 1977, according to Law 2 /1968, a certain number of rural communes got the status of suburban communes and belonged to some of the big cities as towns and by that they increased the urban population at country level.

14) Data of the National Institute for Statistics: "fişa localității, 1990".

15) Dorohoi has been encouraged by investments and developed a more diverse industry, mainly in the '70s, when medium towns got more support from central government in order to balance the development of the counties capital cities (lanoş, 2004). 


\begin{abstract}
"predator" city whereas the small towns were preys. As can be noticed the absolute growth figure of the city of 90,000 inhabitants correspond to the total growth of population during the 4 decades. Most of the other towns, except Dorohoi, had insignificant growth or even losses, especially the former towns that were degraded to rural status. The rapid growth of the urban population was also due to the big flows of rural - urban migration (especially towards medium and big urban centres) combined with the legislation for birth control that was in place since 1966. Due to these factors, the losses of population from the beginning of the interval (also due to massive migration of the Jewish population) were rapidly compensated.
\end{abstract}

The strong focus on the capital city has not favoured the development of a balanced urban structure. Dorohoi remained a medium sized town with a medium growth, whereas the other two towns remained small sized towns with a very slow rhythm of growth. As the communist regime economic development policy was mainly supporting the secondary sector, the agricultural and rural areas were not subject to significant investments in technical and social infrastructure; nor were the small agro-industrial towns. The development of other communal centres such as Truşeşti (capital of a "raion" in the '50s) was encouraged for short periods of time, without significant effects.

At regional level, it is worth to mention that Botoşani city succeeded in the end to keep its third position after laşi and Bacău, after several changes of ranks with other cities (see Fig.8). Yet, it could not regain its second position held during the first decades of the century and will probably not be able to do this in the future. Although being the $3^{\text {rd }}$ in demographic size, the city of Botoşani lacks a very clear and defined regional profile, a certain specific identity within the regional competition. Although it may have won the competition in terms of demographic size, with Suceava - its main competitor and Piatra Neamț, it has a structural weakness, which gives it a marginal role in the region. Botoşani city could not reach the status of a regional administrative, educational or cultural centre, as laşi, neither that of a powerful industrial centre as Bacău did, nor the image of cultural tourism and historic heritage to which Suceava can be connected $^{17)}$.

The political change of December 1989 left the county with a rather strong mono-centric urban structure, quite unbalanced in terms of rank-size rule ${ }^{18)}$ as well as in terms of territorial coverage, as long as the Southern part of the county, about $1 / 3$ of the territory remained still deprived of an urban centre. The urban system left by the communist age was stable but rather weak, depending mostly on two towns only, Botoşani and Dorohoi, the same ones that were the main "players" along history.

\title{
Evolution of the urban system during the last twenty years
}

The last two decades, known as transition period from an authoritarian regime to democracy, were marked by a significant process of economic restructuring, by changes of the property status, by the decrease of investments in infrastructures of the public sector and by the quick development of the private sector. The industry was subject to radical restructuring processes, whereas the tertiary economic sector was fast developing, mainly in connection to the private

17) Suceava has also the advantage of being one of the past medieval Moldavian capitals for almost 200 years during the $14^{\text {th }} 15^{\text {th }}$ and $16^{\text {th }}$ centuries.

18) According to Zipf rank-size rule law, in December 1989 the size of the $2^{\text {nd }}$ city should have been 60,000 inhabitants, of the $3^{\text {rd }}$ one 40,000 and of the $4^{\text {th }}$ one, 30,000 . As compared to the inter-war period, the capital city developed mach faster than the rest of the urban centres, due to strong interventionist development policies. 
sector development. There have been also significant changes of the social and demographic patterns: birth rate decreased (as previous restrictions were abolished), natural increase got negative, the internal migration reversed trend from urban to rural and external migration constantly increased. The European integration process brought the opportunity of accessing Pre-structural Funds from 2000 to 2006 and Structural Funds after 2007. Besides these macro-economic and external factors, there have been significant changes in relation to local governance too: local communities got a certain level of autonomy as part of the decentralisation process that began in the '90s. Towns and cities had to elect their own local authorities and these ones were facing the challenge of planning and managing local development in a competitive environment.

The period following December 1989, is characterized as a period of general turbulence both at the individual level of every town and city and at the level of the national and regional urban systems. lanoş finds as main causes of the turbulence and chaotic evolution: "the beginning of political and social-economic decentralisation, abrogation of some demographic restrictions and the beginning of the process of urban deindustrialisation" ${ }^{19}$. . He also adds the effect of land reform, the pressure of former county capitals that have lost this status in 1950 and have been exempted in 1968 too, to get back to their status and to the territorial division of the inter-war period and finally, the freedom of travelling and settling ones residence ${ }^{20}$.

The urban system of Botoşani County has suffered and was influenced by most of these changes and factors and not in a positive way. What was the heritage of the urban system at the dawns of democracy and market economy? The main traits are listed below:

- an unbalanced urban system with a hypertrophy of the capital, which concentrated most of the economic and human resources and social and technical infrastructure;

- a former county capital, Dorohoi, whose role and importance have been considerably reduced during the 4 decades of communist regime as compared to the period when it was a county capital;

- a pair of two small towns whose urban evolution has been brutally stopped between 1950 and 1968 and two others with some tradition of urban history, which have been also brutally deprived of this status in 1950;

- a number of industrial developments artificially implemented between 1960 and 1980, weakly connected to local resources and traditions;

- a rather weak accessibility and connection to the rest of the country (for instance the railway network, one of the oldest in the country, is one-track and non-electrified), combined with the "frontier effect"21), which increased the isolation of the extreme northern and eastern parts of the county.

The effects of the deindustrialisation were the diminishing of salaried people in industrial sector by more than 2.5 times between 1991 and $2004^{22)}$ and the reduction of the activity or closure of most of the existing industrial enterprises. The small mono-industrial towns have suffered the most, but so has Dorohoi. The weight of the labour force in the industrial sector decreased at around $15 \%$ of the total labour force, much less than the regional and national averages. The

19) lanoş, I. (2004), Dinamica urbană, ed. Tehnică, Bucureşti, pag. 129.

20) Id. Pag. 130-138.

21) The frontier or border effect is related to all types of spatial interactions between countries and regions (Goodall, 1987). In the case of the Eastern Europe communist countries, it refers to the restrictions for traffic, mobility and social interactions imposed usually along all the borders on stripes of land of 25-30 $\mathrm{km}$ large, due to military, strategic and political reasons. In the case of Botoşani County about one third of the territory was so affected.

22) Territorial Statistics, (2006), INS (the National Institute for Statistics). 
lay-offs in the industrial sector, combined with the process of land restitution led to the diminishing of urban population in favour of rural areas. Yet, the small towns have experienced a slight growth of population due to their semi-urban character. An increase of the occupied population in the primary sector was recorded in all the towns and communes of the county except the capital city. The percentage of occupied population in primary sector was constantly above $50 \%$ of the total labour force, higher than regional or national averages. A process of ruralisation of the county as opposed to the fast urbanisation of previous decades can be noticed especially by mid of the 2000'. The slight recovery of 2007-2008 was counteracted by the economic crisis situation of 2009-2010. In spite of these economic and social transformations, in juridical and statistical terms the urban population of the county increased from $37 \%$ in 1989 to $41.91 \%$ by the $1^{\text {st }}$ of January 2010 .

This "fake" urbanisation can be explained by two factors: reparatory actions (such as conferring Dorohoi the status of city /municipiu in compensation to its past position of county capital, or to Stefăneşti the status of town, also as a reward for its urban history) and local "patriotism" of the elected people who were aiming for more prestige and revenues (which led to the creation of two new towns). As a consequence, the urban system grew by three new towns ${ }^{23)}$ and one old town rose to the status of city (municipiu).

Table 5

The demographic evolution of urban centres during the communist regime

\begin{tabular}{|c|c|c|c|c|c|c|}
\hline & \multirow[b]{2}{*}{ Urban centres } & \multicolumn{4}{|c|}{ Number of inhabitants } & \multirow{2}{*}{$\begin{array}{c}\text { Annual growth } \\
(\%) \\
\end{array}$} \\
\hline & & 1990 & 1992 & 2002 & 2010 & \\
\hline 1 & Botoşani* & 121351 & 126145 & 115070 & 115751 & -0.24 \\
\hline 2 & Dorohoi* & 32697 & 33739 & 30949 & 29920 & -0.44 \\
\hline 3 & Flămânzi** $^{*}$ & 12369 & 11752 & 11799 & 11947 & -0.17 \\
\hline 4 & Darabani & 12169 & 11804 & 11820 & 11646 & -0.22 \\
\hline 5 & Săveni & 8361 & 8475 & 8145 & 8043 & -0.19 \\
\hline 6 & Ştefăneşti** & 5631 & 5485 & 5628 & 5620 & -0.01 \\
\hline 7 & Bucecea** $^{* *}$ & 4993 & 5164 & 5128 & 5165 & 0.17 \\
\hline \multicolumn{2}{|c|}{ Total population } & 470385 & 456008 & 452834 & 448749 & -0.24 \\
\hline \multicolumn{2}{|c|}{ Urban population } & 174578 & 180163 & 165984 & 188092 & 0.37 \\
\hline
\end{tabular}

Source: Censuses statistical data, INS and personal compilations. The figures in bold are corresponding to the status of town during a certain period. One * indicates the status of city (municipiu) and ** indicate the new towns declared.

Table 5 shows an almost general loss of population at the level of individual urban centres, at a close rate to the general decrease of the county population. The social and economic transformations have affected more the two northern towns of the county, especially Dorohoi, which lost $8.5 \%$ of the population in 20 years. If new towns are exempted, the urban population decreases by a $-0.27 \%$ yearly rate, a bit higher than the general rate of $-0.24 \%$. The capital city lost a significant number of population (close to $5 \%$ ), but its regional position has not changed, as its closest competitors lost even more population. However its position can be menaced in

23) The former communes of Bucecea, Flămânzi and Ştefăneşti were declared by laws 79,89 and 81 from 2004 as towns. The town of Dorohoi was declared municipiu by law 104 /1994. 
the near future by both Suceava and Piatra-Neamț. The first one developed new regional functions, such as higher education (see also lanoş, 2004) and has a good cultural and touristic image due to the proximity of the painted churches of Moldavia, which are UNESCO heritage ${ }^{24)}$, whereas the second seems to recover after the shock of the industrial restructuring due to tourism opportunities of the surrounding areas.

The development of the urban system after 2004 is too recent to have produced already visible effects at territorial level. In terms of the general balance of the system, the improvements can be seen from the point of view of territorial coverage, as the South and South-eastern parts of the county have been for long time deprived of urban centres. The commune of Flămânzi was a good choice in terms of population size ${ }^{25)}$ and infrastructure and is well placed along the main access road from the South. Stefăneşti, on the other hand was one the first small commercial towns in the area and is also well placed along the main road coming from laşi, the regional urban centre, and also as a cross-border point with the Republic of Moldova. There are fewer arguments for the selection of Bucecea as being a town, except maybe its past of a "plasa" centre. At present, the urban system is counting 2 cities (municipii), 5 towns and a number of 21 small settlements, of which 16 having less than 1,000 inhabitants and a rather strong rural character. The structural weaknesses of the urban system have not been significantly improved.

\section{Major problems of the present urban system of Botoşani County}

Taking into account the present situation, Botoşani County can be seen as one of middle level of urban development, in statistical terms, as against the national and regional averages. In terms of urbanisation level (\% of urban population out of the total population) the county is under the regional and national figures. It stands also below, in relation to the average number of urban centres or cities per county (regional averages are 7.67 and 2.83 and national ones are 7.78 and 2.49). But, it stands above, in terms of urban density (urban centres per 1000 $\mathrm{km}^{2}$ ) and in-between the national and regional averages in terms of number of rural administrative units per urban centre (see Table 6).

In comparison to the regional neighbour counties, Botoşani can be seen as having a mono-centric urban system, with a dominant capital. At regional level, only laşi -7.27 , has a higher primacy report. Botoşani has the second highest primacy report in the region - 3.87, followed by Suceava -3.60 and Bacău - 3.57. However, the real weaknesses of the urban system of the county are not reflected by quantitative indicators, but mostly by qualitative ones. The real problems can be found in the low levels of physical and social infrastructure of the urban centres of the county and most of all in the weakening of the industrial sector which was the base of urban development during the second half of the last century. The low level of economic attractiveness, the lack of jobs and the general decay of the living standard led to an increase of the external migration and to a loss of the young population (laț, 2010). In order to fulfil their territorial role, the cities and towns of the county must have a minimum level of endowment with social and technical facilities, and must provide a minimum standard of living comfort. Such minimum requirements have been set up by specific regulations and normative acts in 2001 and $2007^{26)}$.

24) The UNESCO heritage site of painted churches of Northern Moldavia has been recently extended to 8 such historic monuments (http://www.unesco.org/new/en/unescol, last accessed the $20^{\text {th }}$ of August 2010).

25) The size of the commune Flămânzi has been increased in both surface and population, in 1977 , by its unification with the neighbouring commune Nicolae Bălcescu. 


\begin{tabular}{|c|c|c|c|c|c|}
\hline \multicolumn{6}{|c|}{ Characteristics of the urban system at county, regional and national levels } \\
\hline \multirow{2}{*}{$\begin{array}{c}\text { Territorial level } \\
\text { (county /region / } \\
\text { country) }\end{array}$} & $\begin{array}{c}\text { Urban } \\
\text { population }\end{array}$ & $\begin{array}{c}\text { Towns } \\
\text { and cities }\end{array}$ & $\begin{array}{c}\text { Cities } \\
\text { (municipii) }\end{array}$ & \multirow{2}{*}{$\begin{array}{c}\text { Urban cen- } \\
\text { tres } / 1000 \\
\text { km }^{2}\end{array}$} & \multirow{2}{*}{$\begin{array}{l}\text { Communes / } \\
\text { urban centre }\end{array}$} \\
\hline & $\%$ & no. & no. & & \\
\hline laşi & 46.89 & 5 & 2 & 0.9 & 18.6 \\
\hline Suceava & 42.86 & 16 & 5 & 1.9 & 6.1 \\
\hline Bacău & 42.53 & 8 & 3 & 1.2 & 10.6 \\
\hline Botoşani & 41.91 & 7 & 2 & 1.4 & 10.1 \\
\hline Vaslui & 41.34 & 5 & 3 & 0.9 & 16.2 \\
\hline Neamț & 37.83 & 5 & 2 & 0.8 & 15.6 \\
\hline Regiunea Nord-est & 43.15 & 46 & 17 & 1.2 & 11.0 \\
\hline România & 55.07 & 320 & 103 & 1.3 & 8.9 \\
\hline
\end{tabular}

Source: Romanian Statistical Yearbook 2009, INS; Population of Romania at 1st of January 2010, INS

Level of fulfilment of minimal quantitative and qualitative indicators for urban settlements as defined by Law $100 / 2007$

\begin{tabular}{|c|l|c|c|c|}
\hline & Urban centres & Population 2010 & $\begin{array}{c}\text { Nr. of criteria } \\
\text { fulfilled out of 17 }\end{array}$ & $\begin{array}{c}\text { Major criteria } \\
\text { out of } \mathbf{8}\end{array}$ \\
\hline 1 & Botoşani & 115751 & 15 & 7 \\
\hline 2 & Dorohoi & 29920 & 8 & 4 \\
\hline 3 & Flămânzi & 11947 & 3 & 1 \\
\hline 4 & Darabani & 11646 & 6 & 3 \\
\hline 5 & Săveni & 8043 & 8 & 1 \\
\hline 6 & Ştefăneşti & 5620 & 3 & 1 \\
\hline 7 & Bucecea & 5165 & 4 & 3 \\
\hline
\end{tabular}

Source: (2010), Update of Territorial Plan of Botoşani County

The table above shows that no urban centre of the county, except the capital, fulfils at least $50 \%$ of the minimal quantitative and qualitative criteria set up by Law $100 / 2007$. The new

26) Law 351 /2001 and Law 100 /2007 for approval of National Territorial Physical Plan - Section IV on Human Settlements Network.

27) Major criteria were considered: the demographic size $(40,000$ inhab. for a city and 10,000 inhab. for a town), the economic criteria (labour force occupation), the endowment of dwellings with utilities (water, bathroom, toilet), the health service, the quality of roads, the preservation of the environment 
declared towns have the worse situation: they fulfil 3 or 4 criteria out of the 17 and maximum 1 out of the basic ones. One may conclude that the set up of these 3 towns has been a rather hasty and unmotivated decision, as long as it was not accompanied by significant public investments in infrastructures. There are also some secondary negative effects of this decision: the diminishing of the opportunities to attract European Funds ${ }^{28)}$ and an increase of the living costs for the local communities.

There are also some basic structural problems of the urban system of Botoşani County. The present urban system is the result of a historic evolution, marked by frequent and strong turbulences: during the last 100 years, the urban settlements of the present county territory were affected by 4 major administrative reforms and several other intermediate ones, by at least 4 major changes of political regimes and by experiencing at least 3 economic models. The lack of continuity and the frequent fragmentation of the evolution - almost every 10-15 years - due to external inputs, hampered the urban system of the county to reach the necessary cohesion and integration. Although there has been an administrative stability for the last 4 decades, the radical political and economic changes, at the mid of this interval, have acted as disturbing factors too. Besides these aspects another one should be added: the low level of planning and management capacities of the local authorities. This situation is proved by the lack of territorial and spatial development strategies at both county and urban levels. Most of the existing development plans are obsolete, being more than 10-12 years old and inefficient and most of all, they are not correlated and integrated to a global and unitary vision ${ }^{29}$.

The economic weaknesses, the low level of infrastructure, the unbalanced development and the low capacity of governance of the local authorities are some main factors that make the present urban structure of the county a fragile one and still vulnerable to the influence of external factors. The North and the West are currently more developed than the East and the South, whereas the border "effect" has not been really counteracted. Such disparities in a rather underdeveloped territory can become powerful restrictive factors for future development, especially along a border area with a high risk for illegal activities. If the eastern area of the county will not escape poverty and isolation, there is an increased risk for the whole county to be seen as a "dead-end" with no external connections, which can also hamper the development of its urban system.

At regional level, although the capital city is ranked the $3^{\text {rd }}$ by demographic size, it has lost a recent competition with Suceava, its closest competitor, which was selected as an Urban Development Pole ${ }^{30)}$, together with Bacău and will largely benefit form the Structural Funds under Priority Axis 1 of the Regional Operational Programme - Regio 2007-2013.

As a final conclusion, the urban system of the county has developed over the last 50 years, but not in a sustainable manner and has to face now major challenges. The capital city has no regional identity and is not playing an important regional role, the second city Dorohoi has decayed continuously over the last 20 years, lacks a clear economic profile and lost much of its

(existence of sewage treatment plants) and the percentage of green areas. Other criteria, set up by the law, refer to social infrastructure, tourism facilities, other technical utilities and waste disposal facilities.

28) The new towns are now forced to compete for Structural Funds with medium and large towns with more resources and experience in planning and project preparation. In some cases, due to their small size they are not even eligible to compete (for instance, for Axis 1 of the Regional Operational Programme - REGIO 2007-2013). By having preserved their rural status, they could have competed with communes of similar size and strength for the European Agricultural and Rural Development Fund (EARDF).

29) Territorial Physical Plan of Botoşani County, (2010), UAUIM.

30) According to the Government Decree 1149 /2008 on growth poles in Romania. 
zonal polarization power, whereas the smaller towns are characterized by low attractiveness and by a strong rural character (Zamfir et. All, 2009).

\section{Policy recommendations}

\begin{tabular}{|c|c|}
\hline STRENGTHS & WEAKNESSES \\
\hline $\begin{array}{l}\text { - a developed capital city, ranked } 3^{\text {rd }} \text { at re- } \\
\text { gional level } \\
\text { - a } 2^{\text {nd }} \text { city with a long history of a county } \\
\text { capital } \\
\text { - a number of smaller cities with urban } \\
\text { tradition and well spread along the county } \\
\text { - a number of communes with potential of } \\
\text { "central places" }\end{array}$ & $\begin{array}{l}\text { - lack of regional identity of the capital city } \\
\text { - economic decay of the } 2^{\text {nd }} \text { city } \\
\text { - low level of endowment with social and } \\
\text { technical facilities of the small towns } \\
\text { - low living standards in most of the cities } \\
\text { - weak communication networks } \\
\text { - weak level of cohesion and integration }\end{array}$ \\
\hline OPPORTUNITIES & THREATS \\
\hline $\begin{array}{l}\text { - European Funds for sustainable urban } \\
\text { development } \\
\text { - European Funds for cross-border }\end{array}$ & $\begin{array}{l}\text { - regional competition among capital cities } \\
\text { - geographic isolation } \\
\text { - increased "border effects" }\end{array}$ \\
\hline
\end{tabular}

The development of the urban system must make use of its strengths and of the opportunities and fight against its weaknesses and threats. A brief SWOT analysis is presented below:

Taking into consideration some of the driving factors listed above, the present structure can be seen as a good start for a more balanced urban system if followed by concrete policies and measures such as:

- support for the economic and social development of the city of Dorohoi, through public investments in adequate infrastructures in order to increase its attractiveness for private investments;

- better use of the opportunity of European Funds to improve the technical and social infrastructure of the small towns of the county;

- more decentralisation of public services towards the small new towns (for instance setting up a hospital unit and a law court in Flămânzi);

- improving the road connections between all urban centres of the county and setting up an inter-urban public transport service to improve connections between them;

- support the development of other urban centres especially in the southern part of the county; potential candidates are the communes of Truşeşti and Albeşti to the East and the commune of Vorona in the South-west corner which has the potential of becoming a monastic touristic centre;

- defining an economic or cultural profile for Botoşani city, by supporting and encouraging the development of higher tertiary sector: R\&D, IT in order to preserve and attract the young labour force.

In order to develop a sound and balanced urban system, the policies should also focus on regional and cross-border objectives and make use of the opportunities of the European Funds. Botoşani can develop for instance, a cooperation policy with the city of Suceava to which it is very close $(45 \mathrm{~km})$ and contribute to the strengthening of the urban system of the northern part 
of the region. It must also make use of its geographical position and of the opportunities of the future development of the road communication network. Botoşani will be close to the $9^{\text {th }}$ PanEuropean Corridor connecting Northern and Southern Europe and also on the direction of a national corridor foreseen to better connect the Northern part of Romania (see Fig. 9).
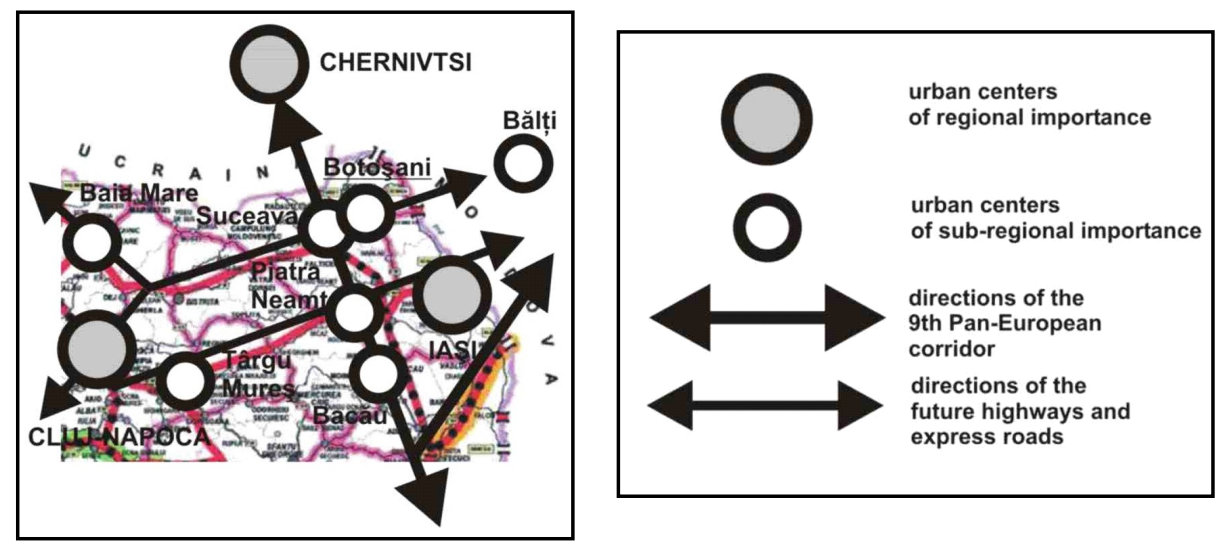

Fig. 9 - Major urban centres and development axis in the North-east of Romania (based on a map from the National Territorial Physical Plan - Section I - Communication network, 2006)

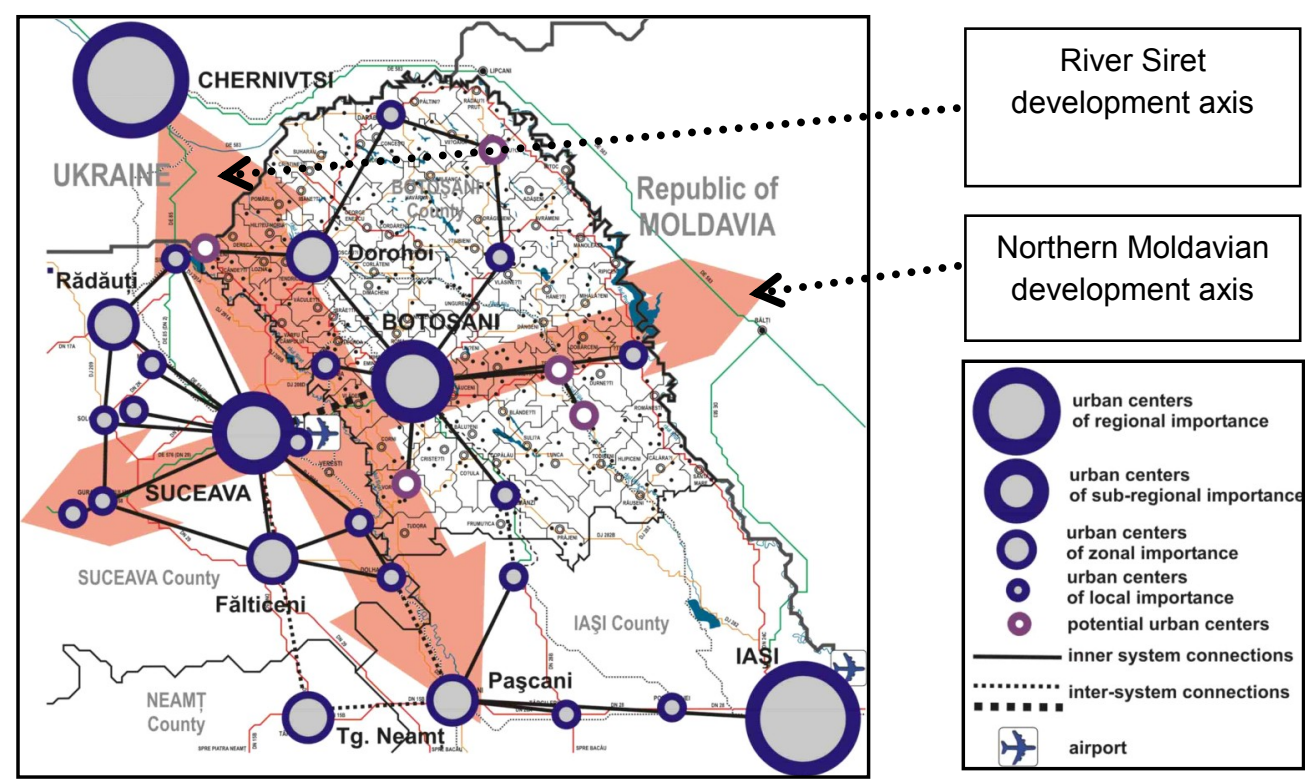

Fig. 10 - Scheme of Botoşani and Suceava counties urban systems and of main connections and development axis (based on maps from Botoşani County Territorial Physical Plan, 2010) 
The urban system of Botoşani County can also evolve to a complex polycentric and more balanced system in correlation to the urban system of Suceava County, its neighbour to the West, usually seen as a competitor. Together, the two counties have now the most developed urban network in the region: exactly half of the total number of towns and cities (23 out of 46) are located here. At least 10 towns and cities are concentrated along the Siret river, the natural border separating the two counties, on a stripe of $40-50 \mathrm{~km}$ width and $70-80 \mathrm{~km}$ length. This corridor is grouping now an urban population of more than 300,000 inhabitants, it also has a rather dense rural population, is well connected by roads and railways to the regional and national territory and benefits of the proximity of an airport (Fig. 10).

By developing a pro-active policy of cooperation with its neighbours at regional and crossborder levels and by making better use of its endogenous potential, the local authorities could better support the development of its urban system, than by isolation and competitive behaviour. In order to make better use of its strengths and transform its weaknesses into strengths too, the internal cooperation of county and local authorities is also necessary as well

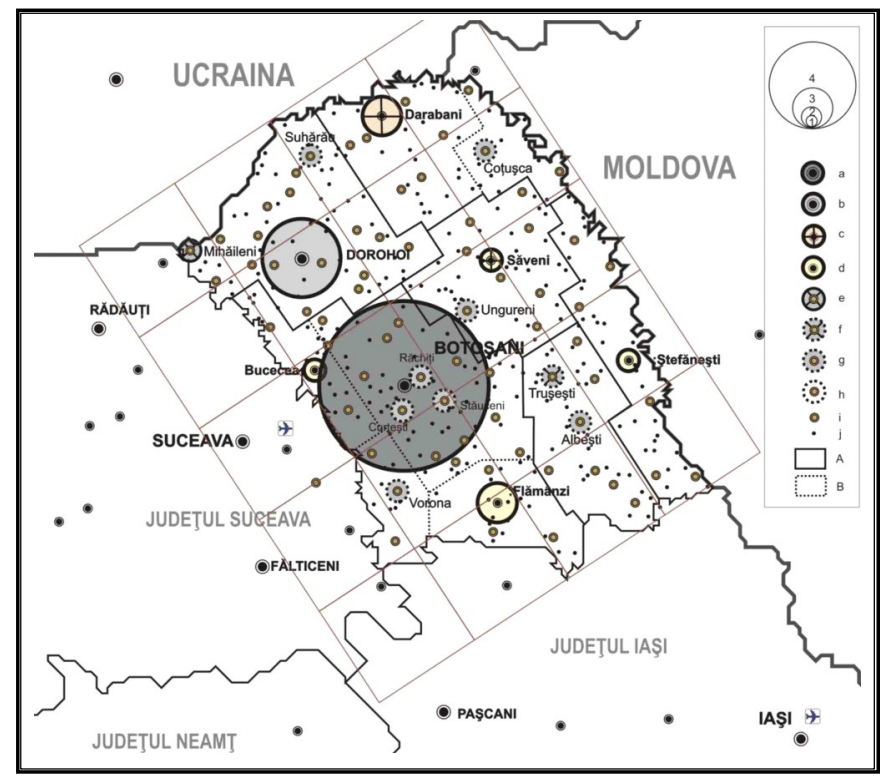

Fig.11 - Urban system of Botoşani County and the human settlements network

Legend

1. small towns under 10,000 inhab.; 2 . small towns of 10,000 to 20,000 inhab.; 3 . medium size towns of 20,000 to 50,000 inhab.; 4 . big cities of over 100,000 inhab.

a. county capital (municipiu); b. other cities (municipii); c. towns since 1968; d. towns since 2004; e. former towns that were degraded to commune; f. former centre of a "raion"; $g$. communes that can be "central places" and potential new towns; h. former sub-urban communes; i. villages, centres of communes; j. villages.

A - main urban systems of the county (Botoşani, Dorohoi, Darabani, Săveni, Ştefăneşti, Truşeşti-Albeşti); B - potential sub-systems (Bucecea, Coțuşca, Flămânzi, Verona). (processed by the author on a topographic support from the Territorial Physical Plan of the county, 2010; the orientation grid is formed by squares of $20 \times 20 \mathrm{~km}$ ) 
as involvement of local communities and private sector. Participatory planning and multi-level governance, that is involvement of different levels of authorities to built up a global vision and strategy, can be key actions for enhancing the urban system of Botoşani County. Some of the possible guidelines for such a strategy could be: development of a bipolar urban system Suceava - Botoşani as a strong growth pole for North-eastern Region, defining specific functions (focusing more on processing local products, education, culture and tourism) for the medium and small towns as part of an integrated system, supporting the border towns and developing smaller local systems of towns and communes in order to provide a better territorial distribution of services and improving the transversal communication over the natural barriers (Siret and Prut rivers), which might need the involvement of regional and national authorities too (see also Fig.11).

\section{Conclusions}

The urban system of Botoşani County has evolved over time under the pressure of various external factors and bearing the geographical disadvantage of being in an extreme marginal border area, at the intersections of many conflicting interests. At present, the political and economic changes are offering new opportunities due to decentralization and local autonomy, European integration and abolition of restrictions of any kind, freedom of economic initiative, of business development and capital circulation. The transformation and evolution of towns and cities are much more depending on local decisions, good management, planning and participation. By developing a global strategy at county level with regional and national correlations, local urban authorities and not only could overcome the restrictive factors of development and make a better use of the driving forces. Significant public investments will be needed in that sense, but these can depend a lot now on the capacity of the public administrations to prepare coherent local development strategies and good projects, eligible for European or national funding. In the end it is the responsibility of local authorities and of local communities to overcame, by integrated and participatory planning, by developing partnerships, the structural weaknesses of the urban system related to geography, infrastructure, social and economic decline and others. A future sustainable urban system of Botoşani County should favour the growth of the smaller towns, increase the role of the only medium-size town of the county and consolidate the regional position of the capital city.

\section{Bibliography}

GHINEA D. (2002), Enciclopedia geografică a României, Editura Enciclopedică, Bucureşti.

GIURESCU C. (1997), Târguri sau oraşe şi cetăți moldovene din secolul al X-lea până la mijlocul secolului al XVI-lea, Editura Enciclopedică, ed. a II-a, Bucureşti.

HANSEN T., IANOŞ I., PASCARIU G., PLATON V., SANDU D. (1996), Regional Disparities in Romania 1990-1994, Rambøll, Guvernul României. Bucureşti.

IANOŞ I, VIĂSCEANU Gh. (1998), Oraşele României, Casa Editorială Odeon,

IANOŞ I. (2004), Dinamica urbană - Aplicații la oraşul şi sistemul urban românesc, Editura Tehnică, Bucureşti.

GOODALL B. (1987), Dictionary of Human Geography, Penguin Books, London.

SĂGEATĂ D.R. (2006), Deciziile poltico-administrative şi organizarea teritoriului, Editura Top-Form, Bucureşti.

ZAMFIR D, TĂLĂNGĂ C, STOICA I.V. (2009), Romanian small towns searching for their identity, Journal of Urban and Regional Analysis, vol. 1, no. 1, p. 41-53.

*** (2002), Recensământul populației şi al locuințelor (Census of population and 
dwellings), Vol. 1, INS

*** (2008, 2009), Anuarul Statistic al României (Romanian Statistical Yearbook), INS.

*** $(2009,2010)$, Eurostat Newsrelease, Eurostat, EC.

*** (2010), Populația României pe localități la 1 ianuarie 2010 (Population of Romania at 1 st of January 2010), INS.

*** (2005) Planul de Dezvoltare Regională al Regiunii Nord-est 2007-2013 (North-east

Regional Development Plan 2007-2013), Agenția de dezvoltare Nord-est.

*** (2005) Planul Național de Dezvoltare 2007-2013

*** (2006) Programul Operațional Regional, REGIO 2007-2013 (Regional Operational Development Programme), Ministry of Regional Development and Tourism (MDRT).

*** (2010), Actualizarea Planului de Amenajare a Județului Botoşani (Update of Territorial Physical Plan of Botoşani County), UAUIM.

*** (1968), Legea 2 din 20 decembrie 1958 privind organizarea administrativă a teritoriului României (Law on administrative reform), Buletinul Oficial al RSR, nr. 163-165 /1968.

*** (1989), Legea 2 din 18 aprilie 1989 privind îmbunătățirea organizării administrative a teritoriului Republicii Socialiste România (Law on administrative reform), Buletinul Oficial al RSR, nr. 151989.

*** (2001) Legea 350 din 6 iulie 2001 privind amenajarea teritoriului şi urbanismului (Law on territorial and urban planning), MO, PI, nr. $373 / 2001$.

*** (2001), Legea 351 din 6 iulie 2001 pentru aprobarea Planului de amenajare a teritoriului național - Secțiunii a IV-a (Law on national human settlements network), MO, PI, nr. $408 / 2001$.

*** (2006), Legea 363 din 21 septembrie 2006, privind aprobarea Planului de amenajare a teritoriului național - Secțiunea I Rețele de transport (Law on transport network), MO, PI, nr. $806 / 2006$.

*** (2007), Legea 100 din 19 aprilie 2007 pentru modificarea şi completarea Legii nr. 351/2001 privind aprobarea Planului de amenajare a teritoriului național - Secțiunea a IV-a Rețeaua de localități, MO, PI nr. 284 /2007.

*** (2008), HG 1149 din 18 septembrie 2008 privind modificarea şi completarea Hotărârii Guvernului nr. 998/2008 pentru desemnarea polilor naționali de creştere în care se realizează cu prioritate investiții din programele cu finanțare comunitară şi națională, MO, PI nr. $719 / 2008$.

Received at : 2.04.2010

Revised at: 15.05 .2010

Accepted for publication at: 13.06.2010 